\title{
Environmental and occupational respiratory diseases - 1044. Prevalence of recurrent wheezing in infants in a poor urban city in South Brazil
}

\author{
Marilyn Urrutia Pereira ${ }^{1 *}$, Juan Carlos Ivancevich², Dirceu Sole ${ }^{3}$, Javier Mallol ${ }^{4}$ \\ From 2nd WAO International Scientific Conference (WISC 2012) \\ Hyderabad, India. 6-9 December 2012
}

\section{Background}

To identify the prevalence of recurrent wheezing in infants in the city of Uruguaiana, RS, Brazil.

\section{Methods}

This is a cross-sectional study, part of the EISL (International Study of Wheezing in Infant). The parents or legal guardians of the infant aged 1-15 months attending health centers for immunization were interviewed and administered the EISL questionnaire, a standardized and validated instrument consisting of questions on demographic characteristics, wheezing, respiratory infections and risk factors during the period between January 2008 and July 2010.

\section{Results}

Sampled infants $(\mathrm{n}=1061)$ had a mean age of 13.09 months with a prevalence of wheezing during their first year of life of $28.56 \% .10,37 \%$ had 3-6 episodes. They lived in a poor area of the city, with low maternal education level $(60,13 \%$ had $\geq 8$ years of formal education) with an income $<500$ US\$ $(99,81 \%)$. The exposure to prenatal maternal smoking was $9,61 \%$, with $12.63 \%$ of maternal smoking and $34,31 \%$ of household smoking. The infant borned by caesarean section were $26,30 \%$ and a mean of breastfeeding of 3-4 months. Maternal history of asthma and rhinitis were $5,02 \%$ and $27,50 \%$ respectively.

\section{Conclusions}

The prevalence of wheezing among infants living in a poor area of Uruguaiana is high. It is necessary to identify

${ }^{1}$ Pediatria, Santa CASA Uruguaiana, Brazil

Full list of author information is available at the end of the article if the risk factors of wheezing in this low socio-economic level population differ from environmental stimuli found in developed countries.

\section{Author details}

${ }^{1}$ Pediatria, Santa CASA Uruguaiana, Brazil. ${ }^{2}$ Cátedra De Inmunología, Universidad Del Salvador, Buenos Aires, Argentina. ${ }^{3}$ Sao Paulo Federal University, Brazilian Society, Sao Paulo, Brazil. ${ }^{4}$ Department of Pediatric and Respiratory Medicine, University of Santiago De Chile (USACH), Santiago, Chile.

Published: 23 April 2013

\section{doi:10.1186/1939-4551-6-S1-P43}

Cite this article as: Pereira et al:: Environmental and occupational respiratory diseases - 1044. Prevalence of recurrent wheezing in infants in a poor urban city in South Brazil. World Allergy Organization Journal 2013 6(Suppl 1):P43.

Submit your next manuscript to BioMed Central and take full advantage of:

- Convenient online submission

- Thorough peer review

- No space constraints or color figure charges

- Immediate publication on acceptance

- Inclusion in PubMed, CAS, Scopus and Google Scholar

- Research which is freely available for redistribution

O 2013 Pereira et al; licensee BioMed Central Ltd. This is an Open Access article distributed under the terms of the Creative Commons 